Relations industrielles

Industrial Relations

\title{
Distinction 1982 de l'Association canadienne des relations industrielles : Gérard Dion \\ Canadian Industrial Relations 1982 Award: Gérard Dion
}

Volume 37, numéro 3, 1982

URI : https://id.erudit.org/iderudit/029275ar

DOI : https://doi.org/10.7202/029275ar

Aller au sommaire du numéro

Éditeur(s)

Département des relations industrielles de l'Université Laval

ISSN

0034-379X (imprimé)

1703-8138 (numérique)

Découvrir la revue

Citer cet article

(1982). Distinction 1982 de l'Association canadienne des relations industrielles :

Gérard Dion. Relations industrielles / Industrial Relations, 37(3), 475-476.

https://doi.org/10.7202/029275ar

Tous droits réservés @ C Département des relations industrielles de l'Université Laval, 1982
Ce document est protégé par la loi sur le droit d'auteur. L'utilisation des services d'Érudit (y compris la reproduction) est assujettie à sa politique d'utilisation que vous pouvez consulter en ligne.

https://apropos.erudit.org/fr/usagers/politique-dutilisation/ 


\section{Distinction 1982 de l'Association canadienne des relations industrielles}

\section{Gérard Dion}

À l'occasion de son congrès annuel tenu à Ottawa en juin 1982, le président sortant de l'A.C.R.I., le professeur Gérard Hébert, a présenté la distinction de l'association dans les termes suivants.

L'A.C.R.I. présente cette année sa distinction annuelle à quelqu'un qui y a droit à plus d'un titre.

D'abord, il fut, avec H.D. Woods, le co-fondateur de notre association et son deuxième président. La rumeur veut que ce soit lui qui ait rédigé notre constitution. Cela se passait autour de 1965.

Mais il oeuvrait dans le domaine des relations industrielles depuis déjà plus de vingt ans. Après avoir obtenu, en 1943, sa maîtrise de la jeune Faculté des sciences sociales de l'Université Laval, il fut aussitôt nommé professeur dans le tout nouveau Département des relations industrielles, le premier dans une université francophone du Canada, quelques années après l'ouverture de celui de Kingston, un an avant l'École de Cornell. Dans ce Département, qu'il incarne depuis lors, il fut tour à tour professeur, secrétaire, directeur-adjoint et directeur.

Son influence a largement dépassé le campus de son université pour s'étendre à tout le Canada, et au-delà. Il a joué un rôle majeur, de multiple façon, dans la formation de tous les universitaires canadiens engagés dans l'enseignement et la recherche en relations industrielles depuis la Seconde guerre mondiale, sans oublier celle de nombreux praticiens.

Son influence la plus constante et la plus étendue s'est exercée par l'intermédiaire de la revue qu'il a contribué à fonder, il y a près de 40 ans, et qu'il dirige encore. Relations industrielles fait la gloire de l'Université Laval, et elle est reconnue par notre association, depuis sa propre fondation, comme son organe officiel. Dès septembre 1945, notre récipiendaire en était le secrétaire; quelques années plus tard, il en devint le directeur; il l'est encore. Commencée comme un Bulletin polycopié d'une dizaine de pages, la revue s'est transformée, au fil des ans, pour suivre l'évolution des relations industrielles au Canada. Sous l'impulsion de son directeur, dynamique et toujours préoccupé de la rajeunir et de l'améliorer, elle est devenue une revue de grande classe, aujourd'hui reconnue dans la communauté universitaire internationale.

Les multiples congrès et symposia de relations industrielles qui se tiennent chaque année au Canada ont plus ou moins imité les conférences annuelles qu'il inaugurait à Québec en 1945.

Plus récemment, il nous a donné un instrument de travail incomparable, à la mesure de la dualité canadienne, le Dictionnaire canadien des relations du travail, dont il poursuit présentement la revision en vue d'une nouvelle édition.

Son influence ne s'est pas limitée au monde universitaire. Les organismes auxquels il a participé et ceux auxquels il collabore, tant au Canada qu'à l'étranger, dans le domaine social, religieux, économique et politique, ne se comptent plus.

Sans diminuer en rien son niveau d'activités - on ne lui donnerait pas ses 70 ans d'âge il y a ajouté, depuis quelques années, un nouveau passe-temps: il collectionne les titres, décorations et honneurs, qu'on lui décerne de Vancouver à Antigonish. Membre de la Société royale du Canada depuis plus de $\mathbf{2 0}$ ans, il est également officier de l'Ordre du Canada.

À cette couronne, il manquait un fleuron. C'est pour nous tous - et pour moi personnellement d'une façon toute particulière - une grande joie et un insigne honneur de lui présenter aujourd'hui, à titre d'ami très cher, de collègue distingué, et notre maître à tous, ce nouveau témoignage d'admiration et de gratitude, la distinction annuelle de l'A.C.R.I. L'abbé Gérard Dion. 


\section{Canadian Industrial Relations 1982 Award Gérard Dion}

At the annual meeting of C.I.R.A., held in Ottawa, June 1982, the A ward of the Association was presented to Professor Gérard Dion. The following citation was read by the President of C.I.R.A., Gérard Hébert.

The nominee for C.I.R.A.'s 1982 Annual Award deserves that honour on many grounds.

He is, with H.D. Woods, the co-founder of our Association, and its second president. Some say that it was he who wrote our constitution. This happened around 1965.

But our nominee had been in the field of industrial relations for already over 20 years. Having obtained, in 1943, a Master's degree in the young Faculty of Social Sciences at Laval University, he was immediately nominated a professor in the brand new Industrial Relations Department, the first in a Canadian francophone university, just a few years after Queen's had opened its own, and one year before the New York State School at Cornell. Ever since, he has in a sense, personified that Department, in which he has been successively a professor, secretary, assistant director and director.

His influence has reached well beyond his own University into every part of Canada and in many countries abroad. In many ways, he has been instrumental in the intellectual development of all Canadian academics involved in industrial relations teaching and research since World War II. He has been as well an inspiration for many industrial relations practitioners.

His most constant and pervasive influence has been through the journal he has worked to establish almost 40 years ago, and of which he is still the director. Relations industrielles/ Industrial Relations has been one of the landmark publications of Laval University; it has also been recognized by our Association, since its own inception, as its of ficial publication. In September 1945, when the journal appeared for the first time, our nominee was its secretary; a few years later, he became its director, and he still holds that office. Having started in the form of a monthly Bulletin of ten or twelve pages, it has evolved progressively into a major quarterly in line with the evolution of industrial relations activity and research in Canada. Under the leadership of its director, always eager to keep the journal in the most up-to-date form, it has become one of the great academic journals, well recognized internationally.

The many industrial relations conferences and symposiums that are conducted every year in Canada have all been inspired by the first conferences that were held in Quebec City since 1945 , under the direction of our young professor.

More recently, our nominee has provided us with a remarkable tool, properly reflective of the Canadian dual culture, the Dictionnaire canadien des relations du travail, with its FrenchEnglish dictionary section, and English-French lexicon. Its author is currently working on a revised second edition.

But the influence of our nominee has not been confined to academic world. The various groups and organizations of which he has been or still is a member, to which he has acted or still acts as a consultant, in Canada and outside, on social, religious, economic and even political matters, are so many that they cannot be counted anymore.

To his various and many activities - he does not look his 70 years of age - he has added recently a new hobby: he is building up a collection of awards, honours, and honorary degrees he has received from Vancouver to Antigonish. He has been for more than 20 years a member of the Royal Society of Canada, and he is an officer of the Order of Canada.

Nevertheless one piece was missing in his collection. This gap is being filled today. It is for all of us - and even more so for me personally - a special pleasure and a great honour to offer him, our beloved friend, distinguished colleague and dearest master, this new token of our admiration and gratefulness, C.I.R.A.'s 1982 Annual Award. Father Gérard Dion. 